Free Speech and Human Dignity 
This page intentionally left blank 
STEVEN J H H M A N

\section{Free Speech and \\ Human Dignity}

Yale University Press

New Haven \&

London 
Published with assistance from the Mary Cady Tew Memorial Fund.

Earlier versions of some of the arguments in this book appeared in the following law journal articles, and they appear here with the following permissions:

Steven J. Heyman, Ideological Conflict and the First Amendment, 78 Chi.-Kent L. Rev. 53 I (2003), by permission of the Chicago-Kent Law Review; Steven J. Heyman, Righting the Balance: An Inquiry into the Foundations and Limits of Freedom of Expression, 78 B.U.L. Rev. I 275 (I998), by permission of the Boston University Law Review; Steven J. Heyman, Spheres of Autonomy: Reforming the Content Neutrality Doctrine in First Amendment Jurisprudence, Iо Wm. \& Mary Bill of Rts. J. 647 (2002), by permission, (c) William \& Mary Bill of Rights Journal.

Copyright (C) 2008 by Steven J. Heyman.

All rights reserved.

This book may not be reproduced, in whole or in part, including illustrations, in any form (beyond that copying permitted by Sections I07 and I08 of the U.S. Copyright Law and except by reviewers for the public press), without written permission from the publishers.

Set in Sabon by Keystone Typesetting, Inc.

Printed in the United States of America.

Library of Congress Cataloging-in-Publication Data

Heyman, Steven J.

Free speech and human dignity / Steven J. Heyman.

p. cm.

Includes bibliographical references and index.

ISBN-I 3: 978-0-300-I I 486-7 (alk. paper)

ISBN-IO: O-300-I I 486-9

I. Freedom of speech - United States. 2. Civil rights - United States.

3. Hate speech - United States. 4. Dignity. I. Title.

KF4772.H49 2008

$342.7308^{\prime} 53-\mathrm{dc}^{2} 2$

200703093 I

A catalogue record for this book is available from the British Library.

The paper in this book meets the guidelines for permanence and durability of the Committee on Production Guidelines for Book Longevity of the Council on Library Resources.

IO $9 \begin{array}{llllllll}8 & 7 & 6 & 5 & 4 & 3 & 2 & \text { I }\end{array}$ 
For Kate and Andrew 
Without freedom of thought, there can be no such thing as wisdom; and no such thing as publick liberty, without freedom of speech: Which is the right of every man, as far as by it he does not hurt and control the right of another.

- Cato's Letters No. I5

Congress shall make no law respecting an establishment of religion, or prohibiting the free exercise thereof; or abridging the freedom of speech, or of the press; or the right of the people peaceably to assemble, and to petition the Government for a redress of grievances.

-First Amendment to the Constitution of the United States 